\title{
Estimated Glucose Measurement
}

National Cancer Institute

\section{Source}

National Cancer Institute. Estimated Glucose Measurement. NCI Thesaurus. Code C147350.

An estimation of the amount of glucose present in a sample. 